prof. dr hab. in;. Krzysztof Magnucki

dr hab. inz. Jerzy Lewiński, prof. Instytutu

dr inz. Hanna Stawecka

Sieć Badawcza Łukasiewicz -

Instytut Pojazdów Szynowych „,TABOR”

\title{
Stress state in the tapered beam bending - Analytical and numerical FEM studies
}

\section{Stan naprężenia w zginanej belce o zmiennej wysokości - badania analityczne i numeryczne MES}

\begin{abstract}
The paper is devoted to comparative analysis of the stress state in bending of a tapered cantilever beam, calculated analytically and numerically (FEM). The analytical model is described based on bibliography, moreover, the numerical FEM model is developed with the use of the SolidWorks software. The results i.e. the stresses obtained by analytical and numerical calculation are compared and specified in Tables and Figures.
\end{abstract}

Praca przestawia analizę porównawcza stanu naprężenia w zginanej belce wspornikowej o zmiennej wysokości. Przeprowadzono obliczenia analityczne $i$ numeryczne metoda elementów skończonych. Model analityczny zostat opisany na podstawie literatury, natomiast model do obliczeń metodq elementów skończonych opracowano z zastosowaniem systemu SolidWorks. Wyniki, tzn. naprężenia wyznaczone analitycznie $i$ numerycznie zostały porównane i zamieszczone $w$ tablicach oraz zilustrowane na rysunkach.

\section{Introduction}

The prismatic beams are most often used in mechanical and building constructions. The nonprismatic beams are also used but less frequently. Gere and Timoshenko [7] described the distribution of the shear stresses (Zhuravsky formula) in the prismatic beams with different cross sections, and also the distribution of the shear stresses in the rectangular cross section of a tapered cantilever beam. Alexandrov et al. [1] and Slivker [13] analogically described these problems of the shear stresses distribution in the rectangular cross section of non-prismatic beams. Zhou and Cheung [14] investigated the tapered Timoshenko beams with the Rayleigh-Ritz method, dealing with their vibrations. The cross section of the considered beam continuously changed according to a power function of the coordinate along the neutral beam axis. Maalek [8] presented deflections of a bent tapered Timoshenko beam with consideration of shear effect. The paper is strictly related to the Gere and Timoshenko [7] model. The values of the deflections obtained analytically have been compared to FEM and experimental results. Auciello and Ercolano [3] proposed a method for analysis of Timoshenko beams with consideration of shearing deformation and rotating inertia. Their procedure was applied to tapered beams as an alternative approach to the usual FEM methods. Dado and Al-Sadder [6] studied large deflections of prismatic and non-prismatic cantilever beams subjected to various loads in vertical and

\section{Wstęp}

W konstrukcjach mechanicznych i budowlanych najczęściej stosuje się belki o stałej wysokości. Belki o zmiennej wysokości również znajdują zastosowanie, lecz niezbyt często. Gere i Timoshenko [7] opisali rozkład naprężeń stycznych (wzór Żurawskiego) w belkach o stałej wysokości i o różnych przekrojach poprzecznych, a także rozkład naprężeń stycznych w belce o zmiennej wysokości i prostokątnym przekroju poprzecznym.

Alexandrov i inni [1] oraz Slivker [13] również zajmowali się rozkładem naprężeń stycznych $\mathrm{w}$ prostokątnym przekroju poprzecznym belki i zmiennej wysokości. Zhou i Cheung [14] badali drgania belki Timoshenki metodą Rayleigha-Ritza. Przekrój poprzeczny badanej belki zmieniał się w sposób ciagły zgodnie z potęgową funkcją współrzędnej biegnącej wzdłuż osi obojętnej belki.

Maalek [8] wyznaczył ugięcie zginanej belki Timoshenki o zmiennej wysokości z uwzględnieniem efektu ścinania. Artykuł ten jest ściśle związany $\mathrm{z}$ modelem Gere i Timoshenki [7]. Wartości ugięcia otrzymane analitycznie porównano z wynikami MES oraz z eksperymentem.

Auciello i Ercolano [3] zaproponowali metodę analizy belki Timoshenki $\mathrm{w}$ uwzględnieniem odkształcenia ścinania. Ich procedurę zastosowano do belek o zmiennej wysokości jako podejście alternatywne w stosunku do zwykłych metod MES. 
horizontal directions. Several numerical examples are presented solved with the use of MSC/NASTRAN computer package. Nevertheless, in case of very large deflections the problems of the solution divergence arose. Rajasekaran [10] investigated buckling of nonprismatic columns with the use of differential quadrature and differential transformation methods. The results are compared with the solutions obtained with other numerical and analytical methods. Attarnejad et al. [2] analysed non-prismatic Timoshenko beams. The concept of Basic Displacement Functions is applied to solve the problem. The numerical examples have shown effectiveness of the method in solving static and free vibration cases. Shahba et al. [12] studied free vibration and stability of axially functionally graded tapered Timoshenko beams. They proposed a finite element using the exact shape functions. The numerical examples have shown good convergence of the method. Rajasekaran [11] dealt with free bending vibration of functionally graded Timoshenko tapered beams. Various boundary conditions are imposed, using differential transformation method and differential quadrature element method. The results are specified in Tables and compared with previously published ones. Auricchio et al. [4] considered a nonprismatic beam. A model of 2D linear-elastic nonprismatic beam is derived, with a corresponding finite element. Numerical results indicated that the proposed model correctly predicts the displacement and stress distributions in these beams. Balduzzi et al. [5] studied a non-prismatic planar beam, developing the compatibility, equilibrium, and constitutive equations. The proposed model is based on standard Timoshenko kinematics of deformation. The model accurately predicts real behaviour of non-prismatic beams, being helpful for the most of practical applications. Magnucki and Lewinski [9] analytically and numerically investigated bending of a prismatic I-beam with consideration of the shear effect. The analytical model is formulated based on the sandwich beam theory. The shear effect is presented for the three-point bending case.

The subject of the study is a tapered cantilever beam of length $L$ with rectangular cross section of width $b$. The depth of the first cross section is $h_{0}$, and the taper angle is $2 \alpha$. The beam is described in the Cartesian coordinate system $x y z$ (Fig.1). Such beams are main structural parts of the railway stock vehicles.

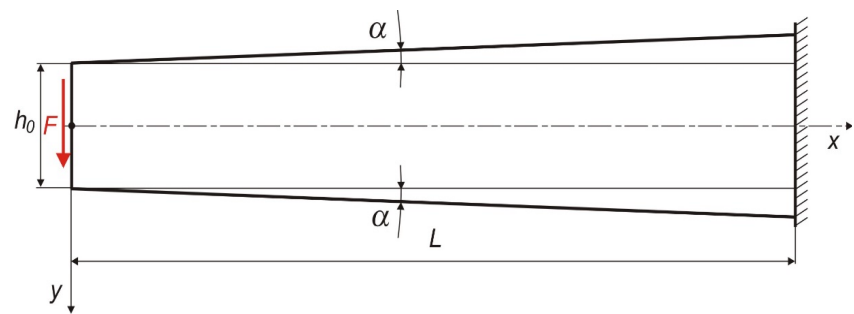

Fig.1. Scheme of the tapered cantilever beam with the load - force F

Rys.1. Schemat belki wspornikowej o zmiennej wysokości obciążonej siłą F
Dado i Al-Sadder [6] badali duże ugięcia belek wspornikowych o stałej i zmiennej wysokości, poddanych różnym obciążeniom $\mathrm{w}$ kierunku pionowym $\mathrm{i}$ poziomym. Przedstawiono kilka przykładów numerycznych rozwiązanych za pomocą systemu MSC/NASTRAN. Jednak w przypadku bardzo dużych ugięć pojawił się problem rozbieżności rozwiązań.

Rajasekaran [10] badał wyboczenie kolumn o zmiennym przekroju, stosując metody kwadratury różniczkowej i transformacji różnicowej. Wyniki porównano z rozwiązaniami uzyskanymi innymi metodami numerycznymi i analitycznymi.

Attarnejad i inni [2] analizowali belki Timoshenki o zmiennej wysokości. Do rozwiązania tego problem zastosowano koncepcję Podstawowych Funkcji Przemieszczenia. Przykłady numeryczne wykazały skuteczność tej metody w zastosowaniu do przypadków statyki i drgań swobodnych.

Shahba i inni [12] badali drgania swobodne i stateczność belek Timoshenki o zmiennej wysokości wykonanych z materiału o funkcjonalnie osiowo zmiennych właściwościach. Zaproponowali element skończony z uwzględnieniem dokładnych funkcji kształtu. Przykłady numeryczne wykazały dobrą zbieżność metody.

Rajasekaran [11] zajmował się giętnymi drganiami swobodnymi belek Timoshenki o zmiennej wysokości wykonanych z materiału o funkcjonalnie zmiennych właściwościach. Zakładano rozmaite warunki brzegowe, z zastosowaniem metody transformacji różniczkowej i różnicowej. Wyniki przedstawiono w tablicach i porównano z opublikowanymi wcześniej.

Auricchio i inni [4] rozważali belkę o zmiennej wysokości. Sformułowano dwuwymiarowy model tej belki posługując się odpowiednim elementem skończonym. Wyniki numeryczne wykazały, że zaproponowany model prawidłowo wyznacza przemieszczenia i rozkład naprężenia w belce.

Balduzzi i inni [5] badali belkę o zmiennej wysokości, formułując równania równowagi i równania konstytutywne. Zaproponowany model sformułowano na podstawie standardowej kinematyki deformacji Timoshenki. Model ten dokładnie przewiduje rzeczywiste zachowanie belek o zmiennej wysokości, służąc jako pomocne narzędzie w większości praktycznych zastosowań.

Magnucki i Lewiński [9] analitycznie i numerycznie badali zginanie dwuteownika o stałej wysokości $\mathrm{z}$ uwzględnieniem efektu ścinania. Model analityczny został opracowany na podstawie teorii belek sandwichowych. Efekt ścinania przedstawiono dla przypadku zginania 3-punktowego.

Przedmiotem niniejszego artykułu jest belka wspornikowa o zmiennej wysokości, o długości $L$ i stałej szerokości przekroju poprzecznego $b$. Wysokość czołowego przekroju poprzecznego wynosi $h_{0}$, a kąt zwężenia jest równy $2 \alpha$. Belka została opsana w kartezjańskim układzie współrzędnych $x y z$ (rys. 1). 
The depth of cross section as a function is in the following form

$$
h(\xi)=(1+2 \xi \tan \alpha) h_{0}
$$

where $\xi=x / h_{0}$ - dimensionless coordinate.

Therefore, the second moment of the cross section

$$
J_{z}(\xi)=\frac{1}{12}(1+2 \xi \tan \alpha)^{3} b h_{0}^{3} .
$$

\section{Analytical study}

The analytical approach is based on the description presented by Alexandrov et al. [1]. Scheme of the element of length $d x$ of the beam with acting forces is shown in Fig.2.

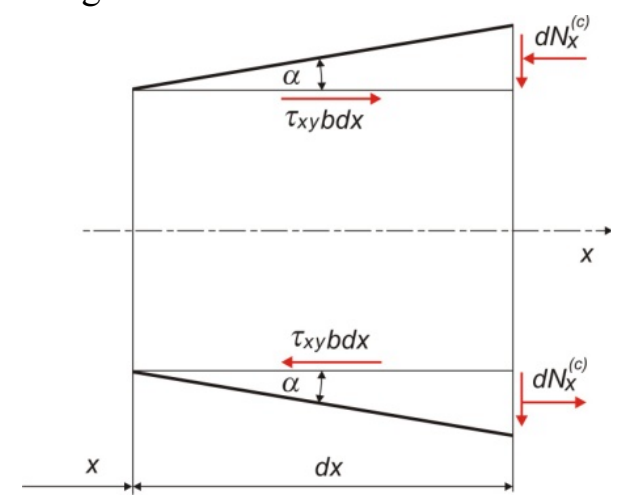

Fig.2. Scheme of the element of the tapered beam with acting forces

Rys. 2. Schemat elementu belki o zmiennej wysokości i siły nań działające

The shear stress, based on the equation of force equilibrium, is as follows

$$
\tau_{x y}=\frac{1}{b} \frac{d N_{x}^{(c)}}{d x}
$$

where $N_{x}^{(c)}=\int_{A^{c}} \sigma_{x} d A$ - the normal force, $A^{(c)}$ - the part of the cross section.

The normal stress

$$
\sigma_{x}=\frac{M_{b}(x)}{J_{z}(x)} y,
$$

where $M_{b}(x)$ - the bending moment.

Therefore, the normal force

$$
N_{x}^{(c)}=M_{b}(x) \frac{S_{z}^{(c)}(x, y)}{J_{z}(x)},
$$

where $S_{z}^{(c)}(x, y)=\int_{A^{(c)}} y d A$ - the first moment of the part of the cross section (Fig.3).

Consequently, after integration, the first moment of the part of the cross section

$$
S_{z}^{(c)}(\xi, \eta)=\frac{1}{8}\left[(1+2 \xi \tan \alpha)^{2}-4 \eta^{2}\right] b h_{0}^{2},
$$

Tego typu belki są podstawowymi częściami konstrukcji taboru kolejowego.

Wysokość przekroju poprzecznego jest wyrażona funkcją o następującej postaci:

$$
h(\xi)=(1+2 \xi \tan \alpha) h_{0}
$$

gdzie $\xi=x / h_{0}$ - współrzędna bezwymiarowa,

zatem drugi moment bezwładności przekroju poprzecznego wynosi

$$
J_{z}(\xi)=\frac{1}{12}(1+2 \xi \tan \alpha)^{3} b h_{0}^{3}
$$

\section{Badania analityczne}

Analityczne podejście do problem sformułowano na podstawie koncepcji przedstawionej przez Alexandrova i innych [1]. Schemat elementu belki o długości $d x$ wraz z działającymi nań siłami pokazano na rys. 2 . $Z$ równowagi sił można wyznaczyć naprężenie styczne w następującej postaci:

$$
\tau_{x y}=\frac{1}{b} \frac{d N_{x}^{(c)}}{d x}
$$

gdzie $N_{x}^{(c)}=\int_{A^{c}} \sigma_{x} d A$ - siła normalna, $A^{(c)}$ - część przekroju poprzecznego.

Naprężenie normalne określa wzór:

$$
\sigma_{x}=\frac{M_{b}(x)}{J_{z}(x)} y
$$

gdzie $M_{b}(x)$ - moment gnący, zatem siła normalna wynosi:

$$
N_{x}^{(c)}=M_{b}(x) \frac{S_{z}^{(c)}(x, y)}{J_{z}(x)}
$$

gdzie $S_{z}^{(c)}(x, y)=\int_{A^{(c)}} y d A$ - moment statyczny części przekroju poprzecznego (rys. 3).

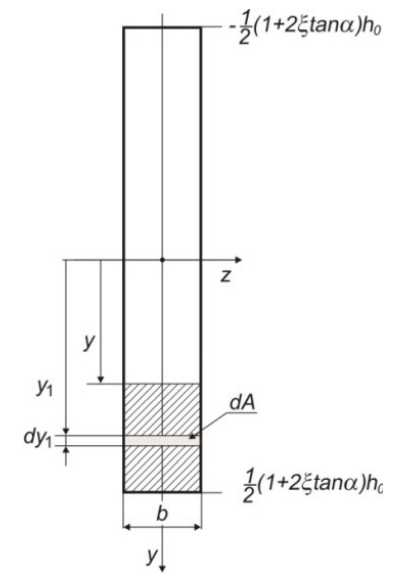

Fig.3. Scheme of the cross section of the beam

Rys.3. Schemat przekroju poprzecznego belki

W rezultacie, po scałkowaniu, moment statyczny części przekroju poprzecznego wynosi:

$$
S_{z}^{(c)}(\xi, \eta)=\frac{1}{8}\left[(1+2 \xi \tan \alpha)^{2}-4 \eta^{2}\right] b h_{0}^{2}
$$


where $\eta=y / h_{0} \quad$ - dimensionless coordinate $\{-(1+2 \xi \tan \alpha) / 2 \leq \eta \leq(1+2 \xi \tan \alpha) / 2\}$.

The shear stress (3) with consideration of the expression (5) is as follows [1]

$\tau_{x y}(x, y)=\frac{1}{b}\left\{Q(x) \frac{S_{z}^{(c)}(x, y)}{J_{z}(x)}+M_{b}(x) \frac{d}{d x}\left[\frac{S_{z}^{(c)}(x, y)}{J_{z}(x)}\right]\right\}$

where $Q(x)=d M_{b} / d x$ - the shear force.

The shear force and the bending moment of the cantilever beam (Fig.1) are as follows:

$$
Q(x)=F, \quad M_{b}(x)=F x=F \xi h_{0} .
$$

Thus, the shear stress (7) with consideration of the expressions (2), (6) and (8) is in the following form

$$
\tau_{x y}=\left[\widetilde{\tau}_{x y}^{(Q)}(\xi, \eta)+\widetilde{\tau}_{x y}^{\left(M_{b}\right)}(\xi, \eta)\right]_{b h_{0}}^{F},
$$

where dimensionless shear stresses

$$
\begin{aligned}
& \tau_{x y}^{(Q)}(\xi, \eta)=\frac{3}{2}\left[(1+2 \xi \tan \alpha)^{2}-4 \eta^{2}\right] \frac{1}{(1+2 \xi \tan \alpha)^{3}}, \\
& \widetilde{\tau}_{x y}^{\left(M_{b}\right)}(\xi, \eta)=3\left[\frac{12 \eta^{2}}{(1+2 \xi \tan \alpha)^{2}}-1\right] \frac{\xi}{(1+2 \xi \tan \alpha)^{2}} \tan \alpha
\end{aligned}
$$

The normal stress

$$
\sigma_{x}(\xi, \eta)=\widetilde{\sigma}_{x}(\xi, \eta) \frac{F}{b h_{0}},
$$

where dimensionless normal stresses

$$
\widetilde{\sigma}_{x}(\xi, \eta)=\frac{12 \xi}{(1+2 \xi \tan \alpha)^{3}} \eta .
$$

Detailed calculations are carried out for the example beam with the taper angle $\alpha=0.07$. Distributions of dimensionless shear stresses in selected cross-sections of the beam are shown in the Fig.4 and Fig.5.
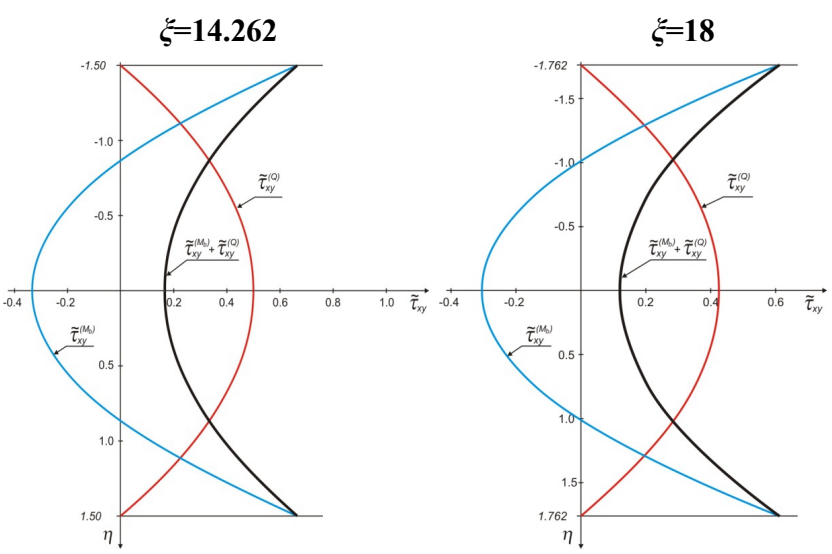

Fig.5. Diagrams of the shear stresses (10), (11) for $\xi=14.262$ and $\xi=18$

Rys. 5. Wykresy naprężeń stycznych (10), (11) dla $\xi=14.262$ i $\xi=18$ gdzie $\eta=y / h_{0}$ - współrzędna bezwymiarowa $\{-(1+2 \xi \tan \alpha) / 2 \leq \eta \leq(1+2 \xi \tan \alpha) / 2\}$.

Biorąc pod uwagę wyrażenie (5) naprężenie styczne (3) przybiera następującą postać [1]:

$\tau_{x y}(x, y)=\frac{1}{b}\left\{Q(x) \frac{S_{z}^{(c)}(x, y)}{J_{z}(x)}+M_{b}(x) \frac{d}{d x}\left[\frac{S_{z}^{(c)}(x, y)}{J_{z}(x)}\right]\right\}$

gdzie $Q(x)=d M_{b} / d x$ - siła styczna.

Siła styczna i moment gnący belki wspornikowej (rys. 1) są następujące:

$$
Q(x)=F, \quad M_{b}(x)=F x=F \xi h_{0}
$$

tak więc, uwzględniając wyrażenia (2), (6) i (8), naprężenie styczne (7) przyjmuje następującą postać

$$
\tau_{x y}=\left[\widetilde{\tau}_{x y}^{(Q)}(\xi, \eta)+\widetilde{\tau}_{x y}^{\left(M_{b}\right)}(\xi, \eta)\right] \frac{F}{b h_{0}},
$$

gdzie bezwymiarowe naprężenia styczne zapisano wyrażeniem:

$$
\begin{array}{r}
\tilde{\tau}_{x y}^{(Q)}(\xi, \eta)=\frac{3}{2}\left[(1+2 \xi \tan \alpha)^{2}-4 \eta^{2}\right] \frac{1}{(1+2 \xi \tan \alpha)^{3}} \\
\widetilde{\tau}_{x y}^{\left(M_{b}\right)}(\xi, \eta)=3\left[\frac{12 \eta^{2}}{(1+2 \xi \tan \alpha)^{2}}-1\right] \frac{\xi}{(1+2 \xi \tan \alpha)^{2}} \tan \alpha
\end{array}
$$

Naprężenie normalne określa zależność:

$$
\sigma_{x}(\xi, \eta)=\widetilde{\sigma}_{x}(\xi, \eta) \frac{F}{b h_{0}}
$$

gdzie bezwymiarowe naprężenie normalne ma postać:

$$
\widetilde{\sigma}_{x}(\xi, \eta)=\frac{12 \xi}{(1+2 \xi \tan \alpha)^{3}} \eta
$$

Szczegółowe obliczenia wykonano dla przykładowej belki o kącie zwężenia zarysu $\alpha=0.07$. Rozkłady bezwymiarowych naprężeń stycznych w wybranych przekrojach poprzecznych belki pokazano na rys. 4 i 5.
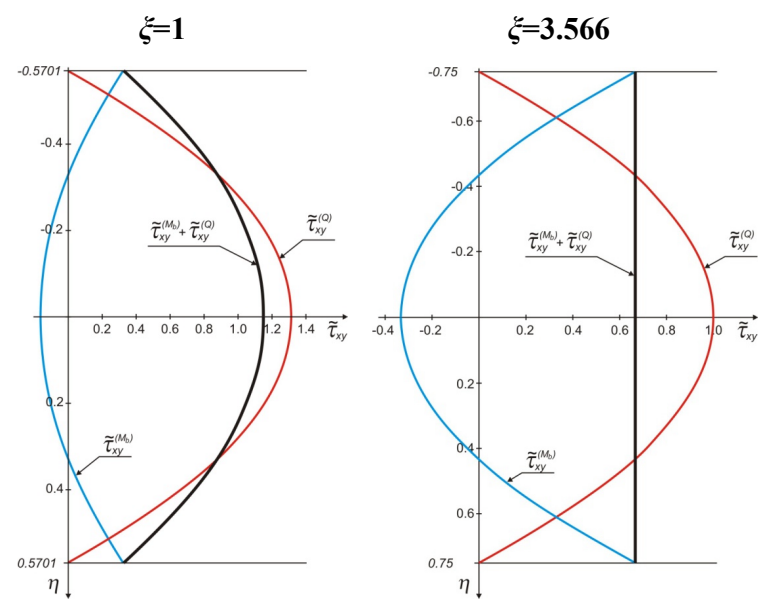

Fig.4. Diagrams of the shear stresses (10), (11) for $\xi=1$ and $\xi=3.566 \quad \xi=14.262 \quad \xi=18$

Rys. 4. Wykresy naprężeń stycznych (10), (11) dla $\xi=1$ i $\xi=3.566$ 
The values of dimensionless shear stresses (10) and (11) in selected cross sections for $\eta=0$ and $\eta=\eta_{b}=(1+2 \xi \tan \alpha) / 2$ are specified in Tab.1.
Wartości bezwymiarowych naprężeń stycznych (10) i (11) w wybranych przekrojach poprzecznych dla $\eta=0 \mathrm{i}$ $\eta=\eta_{b}=(1+2 \xi \tan \alpha) / 2$ są wyszczególnione w tablicy 1 .

\begin{tabular}{|c|c|c|c|c|}
\hline$\xi$ & 1 & 3.566 & 14.262 & 18 \\
\hline$\widetilde{\tau}_{x y}^{(Q)}(\xi, \eta=0)$ & 1.3155 & 1.0 & 0.5 & 0.4256 \\
\hline$\widetilde{\tau}_{x y}^{(Q)}\left(\xi, \eta=\eta_{b}\right)$ & 0 & 0 & 0 & 0 \\
\hline$\widetilde{\tau}_{x y}^{\left(M_{b}\right)}(\xi, \eta=0)$ & -0.1618 & -0.3333 & -0.3333 & -0.3049 \\
\hline$\widetilde{\tau}_{x y}^{\left(M_{b}\right)}\left(\xi, \eta=\eta_{b}\right)$ & 0.3236 & 0.6667 & 0.6667 & 0.6097 \\
\hline
\end{tabular}

Table 1. Values of the dimensionless shear stresses in selected cross sections - Analytical study

Tab. 1. Wartości bezwymiarowych naprężeń stycznych $w$ wybranych przekrojach poprzecznych - badanie analityczne

The outer beam surfaces are unloaded, hence, normal and shear stresses are there equal to zero. The cut out bottom part of the beam is shown in Fig. 6 .

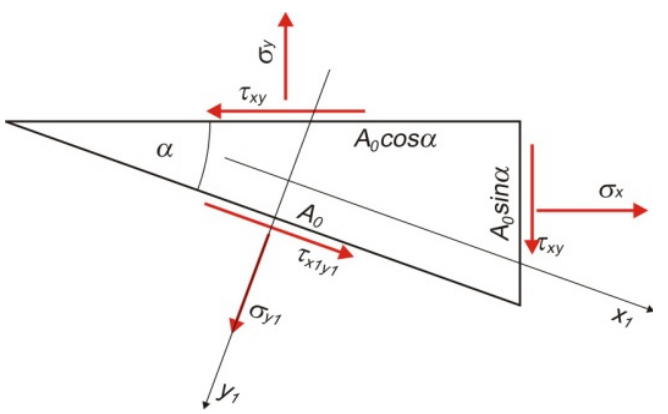

Fig. 6. Scheme of the stresses acting in the bottom part of the beam Rys. 6. Schemat naprężeń działających na dolną część belki

The dimensionless shear (10), (11) and normal stresses (13) at the bottom surface for $\eta=(1+2 \xi \tan \alpha) / 2$, are as follows:

$$
\begin{gathered}
\tau_{x y}^{(Q)}=0, \quad \tau_{x y}^{\left(M_{b}\right)}=\frac{6 \xi}{(1+2 \xi \tan \alpha)^{2}} \tan \alpha, \\
\widetilde{\sigma}_{x}=\frac{6 \xi}{(1+2 \xi \tan \alpha)^{2}}, \quad \widetilde{\sigma}_{y}=\widetilde{\tau}_{x y} \tan \alpha .
\end{gathered}
$$

Therefore, dimensionless shear and normal stresses in the rotated axes $x_{1} y_{1}$, based on the equation of force equilibrium, are as follows

$$
\begin{aligned}
\widetilde{\tau}_{x_{1} y_{1}} & =-\frac{1}{2}\left(\widetilde{\sigma}_{x}-\widetilde{\sigma}_{y}\right) \sin 2 \alpha+\widetilde{\tau}_{x y} \cos 2 \alpha, \\
\widetilde{\sigma}_{y_{1}} & =\widetilde{\sigma}_{x} \sin ^{2} \alpha+\widetilde{\sigma}_{y} \cos ^{2} \alpha-\widetilde{\tau}_{x y} \sin 2 \alpha .
\end{aligned}
$$

Substituting the expressions (14) into (15), one obtains

$$
\tilde{\tau}_{x_{1} y_{1}}=0 \quad \text { and } \quad \widetilde{\sigma}_{y_{1}}=0 .
$$

The presented analysis confirms zeroing of the surface stresses.

The deflection of the beam is calculated with omission of the shear effect, based on the classical differential equation in the dimensionless coordinate, with consideration of the expressions (2) and (8). It takes the following form
Zewnętrzne powierzchnie belki nie są obciążone, zatem naprężenia normalne i styczne są tam równe zeru. Wycięty fragment dolnej części belki pokazano na rys. 6.

Bezwymiarowe naprężenia styczne (10), (11) i normalne (13) na powierzchni dolnej dla $\eta=(1+2 \xi \tan \alpha) / 2$ są następujące:

$$
\begin{gathered}
\tau_{x y}^{(Q)}=0, \widetilde{\tau}_{x y}^{\left(M_{b}\right)}=\frac{6 \xi}{(1+2 \xi \tan \alpha)^{2}} \tan \alpha, \\
\widetilde{\sigma}_{x}=\frac{6 \xi}{(1+2 \xi \tan \alpha)^{2}}, \widetilde{\sigma}_{y}=\widetilde{\tau}_{x y} \tan \alpha .
\end{gathered}
$$

Biorąc pod uwagę równanie równowagi sił wyznacza się następujące bezwymiarowe naprężenia styczne i normalne działające w obróconym układzie współrzędnych $x_{1} y_{1}$

$$
\begin{aligned}
& \tilde{\tau}_{x_{1} y_{1}}=-\frac{1}{2}\left(\widetilde{\sigma}_{x}-\widetilde{\sigma}_{y}\right) \sin 2 \alpha+\widetilde{\tau}_{x y} \cos 2 \alpha, \\
& \widetilde{\sigma}_{y 1}=\widetilde{\sigma}_{x} \sin ^{2} \alpha+\widetilde{\sigma}_{y} \cos ^{2} \alpha-\widetilde{\tau}_{x y} \sin 2 \alpha .
\end{aligned}
$$

Podstawiając wyrażenia (14) do (15) otrzymuje się:

$$
\widetilde{\tau}_{x_{1} y_{1}}=0 \quad \text { i } \quad \widetilde{\sigma}_{y_{1}}=0
$$

Przedstawiona tu analiza potwierdza zerowanie naprężeń na powierzchniach.

Na podstawie klasycznego równania różniczkowego:

$$
\frac{d^{2} v}{d \xi^{2}}=-12 \frac{\xi}{(1+2 \xi \tan \alpha)^{3}} \frac{F}{E b}
$$

zapisanego we współrzędnych bezwymiarowych i z uwzględnieniem wyrażeń (2) i (8), ugięcie belki oblicza się z pominięciem efektu ścinania. Po scałkowaniu tego równania i uwzględnieniu warunków brzegowych $d v /\left.d \xi\right|_{\lambda}=0, v(\lambda)=0$, otrzymuje się ugięcie swobodnego, obciążonego końca belki:

$$
v_{\text {max }}=|v(0)|=\widetilde{v}_{\max } \frac{F}{E b}
$$

gdzie bezwymiarowe maksymalne ugięcie wynosi: 


$$
\frac{d^{2} v}{d \xi^{2}}=-12 \frac{\xi}{(1+2 \xi \tan \alpha)^{3}} \frac{F}{E b} .
$$

After integration of the equation and with consideration of two boundary conditions: $d v /\left.d \xi\right|_{\lambda}=0, v(\lambda)=0$, one obtains the deflection of the free unloaded end

$$
v_{\max }=|v(0)|=\widetilde{v}_{\max } \frac{F}{E b},
$$

where dimensionless maximum deflection

$$
\widetilde{v}_{\max }=\frac{3}{2}\left[\ln (1+2 \lambda \tan \alpha)-2 \lambda \frac{1+3 \lambda \tan \alpha}{(1+2 \lambda \tan \alpha)^{2}} \tan \alpha\right] \frac{1}{\tan ^{3} \alpha} \text {. }
$$

The value of the deflection for the example beam of relative length $\lambda=20$ and the taper angle $\alpha=0.07$ is $\widetilde{v}_{\max }=1424.53$.

\section{Numerical FEM study}

Numerical analysis of the beams is carried out with the SolidWorks software. The geometric parameters and mechanical properties adopted for purpose of the numerical simulation of the beam are equal to the ones used in the analytical approach. Taking into account the vertical plane of symmetry of the structure the model is confined to a half of the whole beam and subjected to the boundary conditions simulating a constrained beam (Fig. 7a).

Longitudinal middle plane of the beam coincides with $x y$-plane of the coordinate system of the model. The $x$ axis is collinear with its neutral axis, while $y$-axis is downward directed. In consequence, the considered half of the beam is placed in the area of positive $z$ values (Fig. 7b).

The boundary conditions illustrated in Fig $7 \mathrm{a}$ are as follows:

- the wall for $x=L$ is clamped;

- the $z$ displacement are zeroed on the wall coinciding with $x y$-plane of the coordinate system, i.e. the vertical plane of beam symmetry.

The model is generated as a single part and divided into ca. 112000 3D tetrahedral finite elements with 16 Jacobian points. A part of the mesh is shown in Fig. 8.

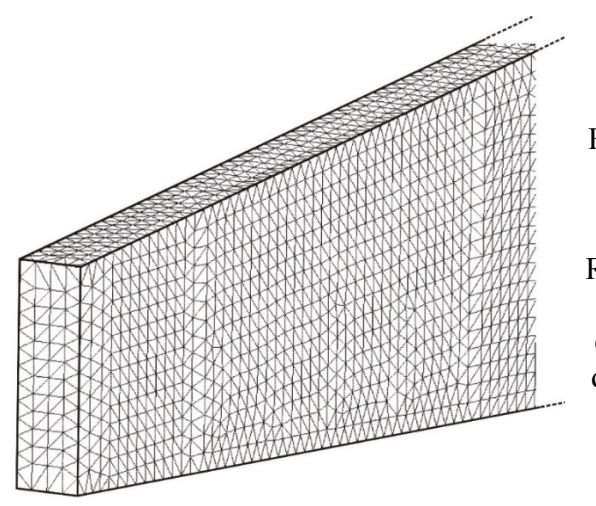

Fig. 8. A part of the half beam model mesh

Rys. 8. Część siatki elementów skończonych należącej do modelu połowy belki $\widetilde{v}_{\max }=\frac{3}{2}\left[\ln (1+2 \lambda \tan \alpha)-2 \lambda \frac{1+3 \lambda \tan \alpha}{(1+2 \lambda \tan \alpha)^{2}} \tan \alpha\right] \frac{1}{\tan ^{3} \alpha}$

Wartość ugięcia w przypadku przykładowej belki o względnej długości $\lambda=20$ i kącie zwężenia zarysu $\alpha=0.07$ wynosi $\widetilde{v}_{\max }=1424.53$.

\section{Badanie numeryczne MES}

Numeryczną analizę belek przeprowadzono z zastosowaniem programu SolidWorks. Parametry geometryczne i właściwości mechaniczne przyjęte dla potrzeb numerycznej symulacji belki są takie same, jakie przyjęto $\mathrm{w}$ postepowaniu analitycznym. Biorąc pod uwagę pionową płaszczyznę symetrii tej struktury model ogranicza się do połowy całej belki i poddany jest warunkom brzegowym symulującym belkę utwierdzoną (rys. 7a).

Podłużna środkowa płaszczyzna belki pokrywa się z płaszczyzną $x y$ układu współrzędnych przyjętego dla modelu. Oś $x$ jest wpółliniowa $z$ osią neutralna, natomiast oś $y$ zwrócona jest w dół.W rezultacie rozważana połowa belki znajduje się w obszarze dodatnich wartość $z$ (rys. 7b). a)

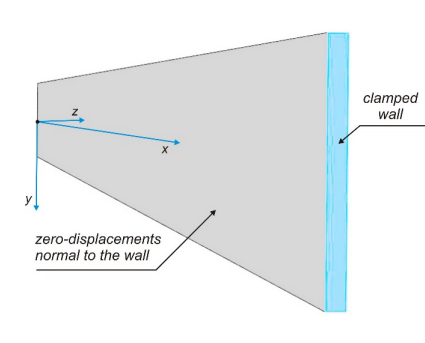

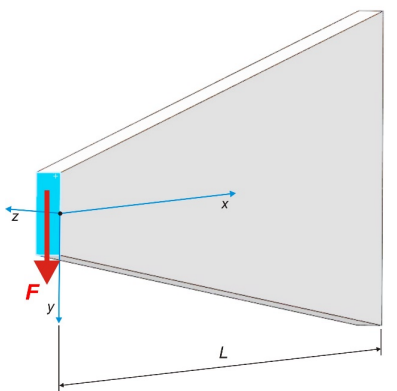

b)
Opis: clamped edge - utwierdzony brzeg, zero-displacements ...zerowe przemieszczenia prostopadte do płaszczyzny

Fig. 7. The half beam model: a) boundary conditions; b) load Rys. 7. Model połowy belki: a) warunki brzegowe; b) obciążenie

Warunki brzegowe przedstawiona na rys. 7a są następujące:

- płaszczyzna $x=L$ jest utwierdzona

- przemieszczenia kierunku osi $z$ zerują się na ścianie pokrywającej się $\mathrm{z}$ płaszczyzną xy układu współrzędnych, tzn. pionową płaszczyzną symetrii belki.

Model został utworzony jako pojedyncza część i podzielono go na około 112.000 czworościennych 3wymiarowych elementów skończonych z 16 punktami Jakobianu. Część tej siatki elementów widoczna jest na rys. 8.

Wartości bezwymiarowych naprężeń stycznych wyznaczonych za pomocą SolidWorks w wybranych przekrojach poprzecznych dla $\eta=0$ i $\eta=\eta_{b}=$ $(1+2 \xi \tan \alpha) / 2$ zamieszczono w tablicy 2 . 
The values of dimensionless shear stresses calculated with SolidWorks system (FEM) in selected cross sections for $\eta=0$ and $\eta=\eta_{b}=(1+2 \xi \tan \alpha) / 2$ are specified in Tab.2.

The numerically calculated dimensionless deflection of the example beam of relative length $\lambda=20$ and taper angle $\alpha=0.07$ amounts to $\widetilde{v}_{\max }^{(F E M)}=1446.48$.

\section{Comparative analysis}

Based on the expression (9) the total dimensionless shear stresses in selected cross sections analytically calculated are as follows

$$
\widetilde{\tau}_{x y}^{(A n)}(\xi, \eta)=\widetilde{\tau}_{x y}^{(Q)}(\xi, \eta)+\widetilde{\tau}_{x y}^{\left(M_{b}\right)}(\xi, \eta) .
$$

The values of these stresses in selected cross sections are specified in Tab.3.

The diagrams of the shear stresses (20) for $\eta=0$ are shown in Fig. 9 and for $\eta=\eta_{b}$ in Fig. 10

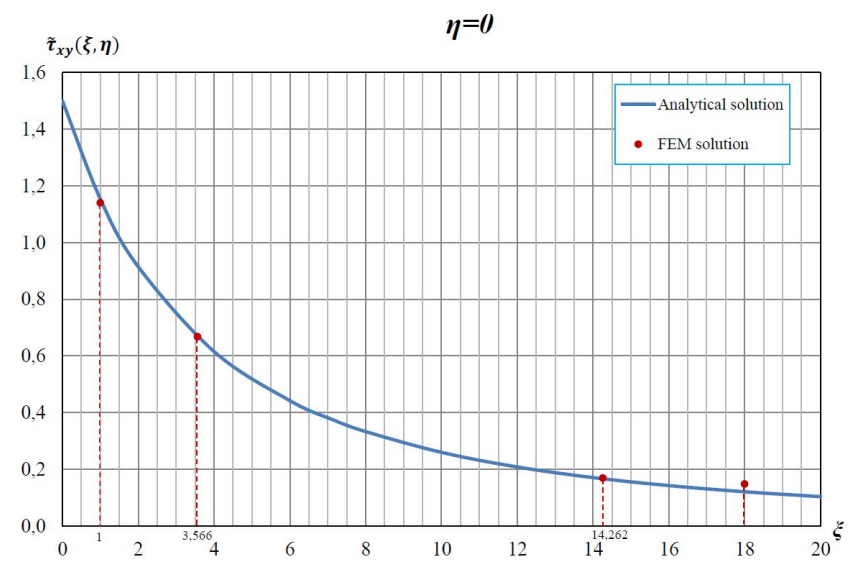

Fig. 9. Comparison of the total dimensionless shear stresses in selected cross sections for $\eta=0$

Rys. 9. Porównanie całkowitego bezwymiarowego naprężenia stycznego w wybranych przekrojach poprzecznych belki dla $\eta=0$ Opis: Analytical solution - rozwiqzanie analityczne, FEM solution - rozwiqzanie metoda FEM

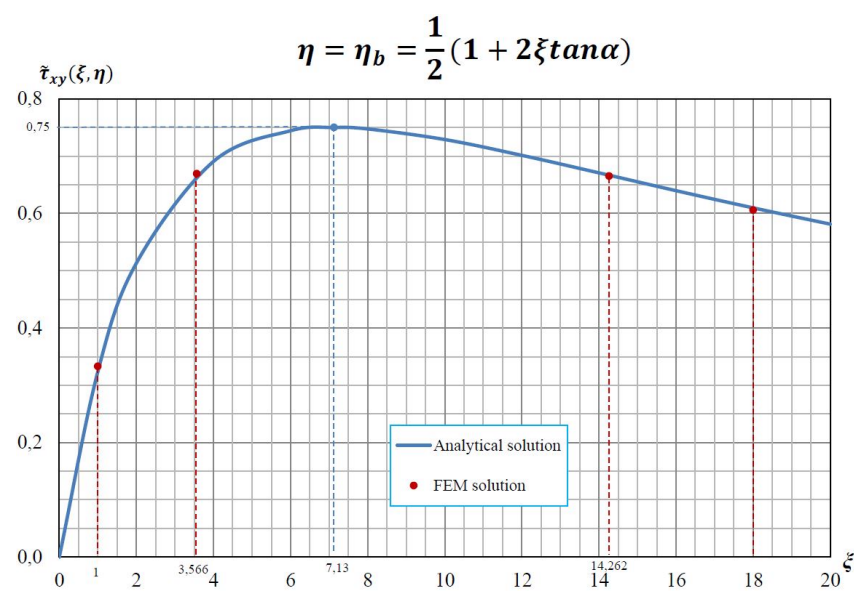

Fig. 10. Comparison of the total dimensionless shear stresses in selected cross sections for $\eta=\eta_{b}$

Rys. 10. Porównanie całkowitego bezwymiarowego naprężenia stycznego w wybranych przekrojach poprzecznych belki dla $\eta=\eta_{\mathrm{b}}$ Opis: Analytical solution - rozwiazanie analityczne, FEM solution - rozwiazanie metoda FEM
Table 2. Values of the dimensionless shear stresses in selected cross sections - FEM study

Tab. 2. Wartości bezwymiarowych naprężeń stycznych w wybranych przekrojach poprzecznych - badanie MES

\begin{tabular}{|c|c|c|c|c|}
\hline$\xi$ & 1 & 3.566 & 14.262 & 18 \\
\hline$\widetilde{\tau}_{x y}^{(F E M)}(\xi, \eta=0)$ & 1.1406 & 0.6678 & 0.1689 & 0.1483 \\
\hline$\widetilde{\tau}_{x y}^{(F E M)}\left(\xi, \eta=\eta_{b}\right)$ & 0.3331 & 0.6696 & 0.6654 & 0.6060 \\
\hline
\end{tabular}

Table 3. Values of the total dimensionless shear stresses in selected cross sections - Analytical study

Tab. 3. Wartości całkowitego bezwymiarowego naprężenia stycznego w wybranych przekrojach poprzecznych belki badanie analityczne

\begin{tabular}{|c|c|c|c|c|}
\hline$\xi$ & 1 & 3.566 & 14.262 & 18 \\
\hline$\widetilde{\tau}_{x y}^{(A n)}(\xi, \eta=0)$ & 1.1537 & 0.6667 & 0.1667 & 0.1207 \\
\hline$\widetilde{\tau}_{x y}^{(A n)}\left(\xi, \eta=\eta_{b}\right)$ & 0.3236 & 0.6667 & 0.6667 & 0.6097 \\
\hline
\end{tabular}

\section{Analiza porównawcza}

Na podstawie wyrażenia (9) analitycznie wyznaczone całkowite bezwymiarowe naprężenie styczne w wybranych przekrojach poprzecznych belki wynosi

$$
\tilde{\tau}_{x y}^{(A n)}(\xi, \eta)=\widetilde{\tau}_{x y}^{(Q)}(\xi, \eta)+\widetilde{\tau}_{x y}^{\left(M_{b}\right)}(\xi, \eta)
$$

Wartości tego naprężenia $\mathrm{w}$ wybranych przekrojach poprzecznych belki są podane w tablicy 3 .

Wykresy naprężenia stycznego (20), a także niektóre wartości wyznaczone numerycznie (MES) dla $\eta=0$, pokazano na rys. 9 , a dla $\eta=\eta_{b}$ na rys. 10 .

\section{Wnioski}

Prezentowane rozwiązanie analityczne uzyskane na podstawie literatury zostało potwierdzone obliczeniami numerycznymi MES (SolidWorks). Stwierdza się, że różnice między oboma rozwiązaniami są nieznaczne w zdecydowanej większości badanych punktów (rys. 9 i 10). Największa różnica występuje w osi obojętnej belki $(\eta=0)$ dla $\xi=18$ i wynosi $23 \%$. Jest to jedyny punkt odznaczający się tak znaczną rozbieżnością, która jest efektem oddziaływania utwierdzonego brzegu. Prezentowany problem rozkładu naprężeń tnących ma istotne znaczenie $\mathrm{w}$ konstruowaniu pojazdów szynowych.

\section{Bibliography / Bibliografia}

[1] Alexandrov A.V., Potapov V.D., Derzhavin B.P., Strength of materials, Moscow, Izd. "Vyshaya Shkola” 2003. (in Russian).

[2] Attarnejad R., Semnani S.J., Shahba A., Analysis of non-prismatic Timoshenko beams using basic displacement functions, Advances in Structural Engineering, 14(2): 319-332, 2011.

[3] Auciello N.M., Ercolano A., A general solution for dynamic response of axially loaded non-uniform Timoshenko beams, International Journal of Solids and Structures, 41(18-19): 4861-4874, 2004. 


\section{Conclusions}

The presented analytical solution based on the literature has been confirmed by FEM numerical calculation carried out with the SolidWorks software. It was found that the difference between both solutions is insignificant in most of the examined points (Figs 9 and 10). The largest difference, reaching 23 per cent, exists in neutral axis of the beam $(\eta=0)$ for $\xi=18$. This is the only point distinguished by such a significant discrepancy, due to the effect of the clamped edge. The problem of shear stress distribution dealt in the present paper is of high importance for designing of the rail vehicles.

[4] Auricchio F., Balduzzi G., Lovadina C., The dimensional reduction approach for $2 D$ nonprismatic beam modelling: A solution based on Hellinger-Reissner principle, International Journal of Solids and Structures, 63: 264-276, 2015.

[5] Balduzzi G., Aminbaghai M., Sacco E., Füssl J., Eberhardsteiner J., Auricchio F., Non-prismatic beams: A simple and effective Timoshenko-like model, International Journal of Solids and Structures, 90: 236-250, 2016.

[6] Dado M., Al-Sadder S., A new technique for large deflection analysis of non-prismatic cantilever beams, Mechanics Research Communications, 32(6): 692-703, 2005.
[7] Gere J.M., Timoshenko S.P., Mechanics of Materials, (Second Edition) Boston, PWS-KENT Pub. Comp. 1984.

[8] Maalek S., Shear deflections of tapered Timoshenko beams, International Journal of Mechanical Sciences, 46(5): 783-805, 2004.

[9] Magnucki K., Lewinski J., Analytical modeling of Ibeam as a sandwich structures, Engineering Transactions, 66(4): 357-373, 2018.

[10] Rajasekaran S., Buckling of fully and partially embedded non-prismatic columns using differential quadrature and differential transformation methods, Structural Engineering and Mechanics, 28(2): 221238, 2008.

[11] Rajasekaran S., Free vibration of centrifugally stiffened axially functionally graded tapered Timoshenko beams using differential transformation and quadrature methods, Applied Mathematical Modelling, 37(6): 4440-4463, 2013.

[12] Shahba A., Attarnejad R., Marvi M.T., Hajilar S., Free vibration and stability analysis of axially functionally graded tapered Timoshenko beams with classical and non-classical boundary conditions, Composites Part B: Engineering, 42(4): 801-808, 2011.

[13] Slivker V.I., Structural mechanics, Moscow, Pub. Assoc. Structural 2005. (in Russian).

[14] Zhou D., Cheung K., Vibrations of Tapered Timoshenko Beams in Terms of Static Timoshenko Beam Functions, Journal of Applied Mechanics, 68(4): 596-602, 2001. 